\title{
Effect of lipid source and emulsifier on productive and physiological parameters of broilers
}

\author{
Karine Isabela Tenório ${ }^{1}$, Cinthia Eyng ${ }^{1}{ }^{*}$, Cristiane Regina do Amaral Duarte ${ }^{2}$, Ricardo Vianna Nunes ${ }^{1}$, \\ Jomara Broch ${ }^{1}$, Nilton Rohloff Júnior ${ }^{1}$, Tânia Luiza Köhler ${ }^{1}$, and Edinan Hagdon Cirilo ${ }^{1}$
}

\begin{abstract}
* Corresponding Author: Cinthia Eyng Tel: +55-45-3284-7878

E-mail: cinthiaeyng@hotmail.com
\end{abstract}

'Department of Animal Science, Western Paraná State University, Unioeste, Marechal Cândido Rondon, PR, 85960-000, Brazil

2 Department of Biological Sciences, State

University of Mato Grosso, Unemat, Tangará da Serra, MT, 78300-000, Brazil

ORCID

Karine Isabela Tenório

https://orcid.org/0000-0003-0142-9629

Cinthia Eyng

https://orcid.org/0000-0001-8839-3758

Cristiane Regina do Amaral Duarte

https://orcid.org/0000-0003-3209-3814

Ricardo Vianna Nunes

https://orcid.org/0000-0002-9376-2826 Jomara Broch

https://orcid.org/0000-0002-0799-9473

Nilton Rohloff Júnior

https://orcid.org/0000-0002-7146-7295

Tânia Luiza Köhler

https://orcid.org/0000-0002-1916-4801

Edinan Hagdon Cirilo

https://orcid.org/0000-0001-7268-2870

Submitted Sept 2, 2020; Revised Sept 22, 2020; Accepted Dec 5, 2020
Objective: This study aimed to evaluate the replacement of degummed soybean oil (DSO) by acid soybean oil (ASO) in diets with or without the inclusion of emulsifier on broiler performance, relative organ weight, lipase activity, intestinal morphometry, and nutrient digestibility.

Methods: A total of 7041 -day-old male broiler chicks were allotted to a $2 \times 2$ completely randomized factorial design (with or without emulsifier $\times$ two lipid sources [ASO and DSO]), with eight replicates and 22 birds each. The metabolizable energy level in diets with emulsifier was reduced by $40 \mathrm{kcal} / \mathrm{kg}$ from 1 to $21 \mathrm{~d}$ and $50 \mathrm{kcal} / \mathrm{kg}$ from 22 to $49 \mathrm{~d}$.

Results: Broilers fed diets containing ASO without emulsifier had higher $(\mathrm{p}=0.005)$ weight gain than DSO-fed animals and with the inclusion of emulsifier had worse $(p=0.018)$ feed conversion ratio (FCR). Birds fed diets with emulsifier worsened FCR regardless of lipid source from 1 to 21 days $(\mathrm{p}=0.006)$ and from 1 to 49 days $(\mathrm{p}=0.0002)$. There was an increase $(\mathrm{p}=0.026)$ in the relative pancreas weight, at 14 days, in birds fed diets containing ASO. Lipase activity and morphometry of the duodenum and jejunum, at 14 and 21 days, were not affected $(\mathrm{p}>0.05)$. The dietary inclusion of emulsifier improved the digestible energy ( $\mathrm{p}$ $=0.053$ ) in the presence of ASO. For the digestibility coefficients (gross energy, crude protein, and mineral matter), no interference was observed ( $\mathrm{p}>0.05)$.

Conclusion: The inclusion of emulsifier to energy-restricted diet with ASO maintained broiler performance in the first week, but worsened FCR in subsequent phases. The ASO can be considered as an alternative lipid source to DSO and does not interfere with the morphophysiological characteristics and performance of broilers. The combination of ASO and emulsifier increased the digestible energy content by $6.2 \%$.

Keywords: Acid Soybean Oil; Degummed Soybean Oil; Exogenous Emulsifier; Ileal Digestibility; Pancreatic Lipase

\section{INTRODUCTION}

The inclusion of lipids in poultry diets is essential to meet energy requirements and achieve high animal performance. Lipid sources are added to diets at an average level of $3 \%$ in the starter phase, reaching up to 7\% in the finisher phase [1]. Degummed soybean oil (DSO), the main lipid source used in the industry, is expensive, and therefore, acid soybean oil (ASO), which is a residue obtained from the neutralization of soybean oil for human consumption, has aroused the interest of the livestock industry [2]. This by-product has been considered an adequate energy source $(7,153 \mathrm{kcal} / \mathrm{kg}$ dry matter $[\mathrm{DM}]$ of metabolizable energy) compared to soybean oil $(8,825 \mathrm{kcal} / \mathrm{kg} \mathrm{DM}$ of metabolizable energy) [1,3], and based on the price in Brazil (September/2020), the cost of ASO may be 37.1\% lower than of DSO.

However, the chemical structure of fatty acids in ASO differs from that of fatty acids 
in soybean oil. Compared to DSO, the ASO presents low percentages of linoleic acid, linolenic acid, and total polyunsaturated fatty acids and a higher amount of total monounsaturated fatty acids and oleic acid [2]. In addition, this by-product has a high content of free fatty acids, which can directly affect its nutritional value. The high content of free fatty acids is correlated with decreased energy use due to reduced micellar affinity, thus interfering with the absorption process. Moreover, free fatty acids have a high capacity to form insoluble soaps with divalent minerals [4].

Broiler age is another factor that interferes with lipid use. The ability to digest lipids in broilers, especially in the starter phase, is limited by low lipase synthesis and low production of bile salts [5]. Therefore, the dietary inclusion of an emulsifying agent could be used as a strategy to compensate for the differences in the chemical characteristics of lipid sources and to overcome the physiological limitations of birds. Emulsifiers reduce the surface tension of lipid droplets and allow physical agitation by the gastrointestinal tract to break them into smaller particles, thus increasing lipid digestion. Moreover, emulsifiers are involved in micelle formation, which facilitates the absorption of dietary lipids. Studies show that a glyceryl polyethyleneglycol ricinoleate-based emulsifier improves the performance and lipid digestibility in poultry and pigs. Roy et al [6] found that the dietary inclusion of emulsifier at a dose of $1 \%$ of added fat (saturated palm oil) increased the live weight of broilers by approximately $5 \%$ at an age of 39 days. Kaczmarek et al [7] observed that dietary supplementation of emulsifier at a concentration of $0.04 \%$ caused a higher apparent total tract digestibility of ether extract by $5.4 \%$ and $4.8 \%$ for broilers at $\mathrm{d} 14$ and 35 , respectively. In addition, Udomprasert and Rukkwamsuk [8] observed an improvement in average daily gain of $19.65 \mathrm{gm} / \mathrm{d}$ and 0.06 in the feed conversion ratio (FCR) of pigs fed diets containing $5 \%$ of crude soybean oil and $1 \%$ of emulsifier.

We hypothesize that ASO is an alternative to DSO in diets for broilers. Furthermore, the dietary inclusion of emulsifier would favor the digestion of these lipid sources, providing energy and enhancing broiler performance, especially in the starter phase, allowing the possibility to reduce energy in poultry diets. Thus, we evaluated the effect of replacing DSO with ASO in diets reduced in metabolizable energy with the inclusion of a glyceryl polyethyleneglycol ricinoleate-based emulsifier and in diets without the additive and meeting the energy requirement on broiler performance, relative organ weight, lipase activity, intestinal morphometry, and nutrient digestibility.

\section{MATERIALS AND METHODS}

\section{Animal care}

The procedures involving animals were previously approved by the Ethics and Biosafety Committee of the institution (protocol \#55/19). The broilers were raised according to the ethical guidelines for animal research established by the National Council for Animal Experimentation Control (CONCEA).

\section{Housing, birds, and treatments}

The study was carried out at the Poultry Research Center of the Western Paraná State University - Unioeste, Marechal Cândido Rondon, Paraná, Brazil.

A total of 704 1-day-old Ross 308 AP male broiler chicks with an average initial body weight of $44.04 \pm 0.4 \mathrm{~g}$ from 45 -week-old breeder hens were used. The birds were allotted to a $2 \times 2$ completely randomized factorial design (with or without the inclusion of emulsifier $\times$ two lipid sources [ASO and DSO]), with eight replicates and 22 birds per experimental unit (EU). The birds were housed in $1.76 \mathrm{~m} 2$ boxes provided with clean wood shaving bedding and food and water ad libitum. The lighting program and environment temperature were set as recommended by the Ross $308 \mathrm{AP}$ manual. During the starter period, the environment was heated using electric brooders (250 watts) and circulation fans. If necessary, the environment was cooled using exhaust fans and evaporative cooling pads.

The experimental diets were formulated based on the chemical composition of feed ingredients and the nutritional requirements as proposed by Rostagno et al [1] for intermediate-performance male broilers from 1 to 7,8 to 21,22 to 33,34 to 42 , and 43 to 49 days of age (Tables 1 to 3 ). The glyceryl polyethyleneglycol ricinoleate-based emulsifier was added to diets at $350 \mathrm{~g} / \mathrm{ton}$, according to the manufacturer's recommendation. The recommended metabolizable energy level was reduced by $40 \mathrm{kcal} / \mathrm{kg}$ from 1 to 21 days and 50 $\mathrm{kcal} / \mathrm{kg}$ from 22 to 49 days of age in diets containing the emulsifying agent.

\section{Broiler performance}

Body weight and feed intake of birds of each EU were recorded at seven, 21,35 , and 49 days of age to assess broiler performance (weight gain [WG], average feed intake, and FCR). Mortality was recorded daily for calculation of mortality-adjusted WG according to Sakomura and Rostagno [9].

\section{Relative weight of organs and lipase activity}

At 14 and 21 days of age, one representative bird per EU (mean weight $\pm 5 \%$ ) was selected and slaughtered by cervical dislocation. The liver and pancreas were collected and weighed to calculate the relative organ weight (organ to live body weight ratio). Subsequently, the pancreas was frozen at $-20^{\circ} \mathrm{C}$ for further analysis of pancreatic lipase activity. For this, the pancreas was homogenized using an IKA ultra-Turrax homogenizer $(1: 20 \mathrm{~g} / \mathrm{mL})$ in $50 \mathrm{mM}$ Tris- $\mathrm{HCl}$ buffer solution 
Table 1. Ingredients and chemical composition of experimental diets containing different lipid sources, with or without inclusion of emulsifier, for the pre-starter (1 to 7 days) and starter (8 to 21 days) phases of broilers

\begin{tabular}{|c|c|c|c|c|c|c|c|c|}
\hline \multirow{3}{*}{ Items } & \multicolumn{4}{|c|}{1 to 7 days } & \multicolumn{4}{|c|}{8 to 21 days } \\
\hline & \multicolumn{2}{|c|}{ ASO } & \multicolumn{2}{|c|}{ DSO } & \multicolumn{2}{|c|}{ ASO } & \multicolumn{2}{|c|}{ DSO } \\
\hline & With & Without & With & Without & With & Without & With & Without \\
\hline Corn & 55.96 & 57.15 & 56.62 & 57.55 & 57.41 & 58.60 & 58.31 & 59.26 \\
\hline Soybean meal, $46 \%$ & 34.40 & 34.20 & 34.30 & 34.10 & 32.30 & 32.10 & 32.20 & 32.00 \\
\hline Meat and bone meal, $45 \%$ & 3.00 & 3.00 & 3.00 & 3.00 & 3.00 & 3.00 & 3.00 & 3.00 \\
\hline DSO & - & - & 1.62 & 0.88 & - & - & 2.37 & 1.62 \\
\hline Poultry fat & 1.00 & 1.00 & 1.00 & 1.00 & 1.00 & 1.00 & 1.00 & 1.00 \\
\hline Dicalcium phosphate & 1.097 & 1.096 & 1.097 & 1.095 & 0.878 & 0.877 & 0.877 & 0.876 \\
\hline Limestone & 0.598 & 0.600 & 0.599 & 0.600 & 0.512 & 0.514 & 0.513 & 0.515 \\
\hline $\mathrm{NaCl}$ & 0.479 & 0.479 & 0.479 & 0.479 & 0.462 & 0.462 & 0.462 & 0.462 \\
\hline Mineral supplement ${ }^{1)}$ & 0.050 & 0.050 & 0.050 & 0.050 & 0.050 & 0.050 & 0.050 & 0.050 \\
\hline L-lysine HCL, 50.7\% & 0.489 & 0.495 & 0.492 & 0.496 & 0.488 & 0.494 & 0.493 & 0.497 \\
\hline Choline chloride, $60 \%$ & 0.060 & 0.060 & 0.060 & 0.060 & 0.060 & 0.060 & 0.060 & 0.060 \\
\hline Inert $^{3)}$ & 0.035 & 0.035 & 0.035 & 0.035 & 0.035 & 0.035 & 0.035 & 0.035 \\
\hline ME (kcal/kg) & 2,975 & 2,935 & 2,975 & 2,935 & 3,050 & 3,010 & 3,050 & 3,010 \\
\hline Crude protein (\%) & 21.94 & 21.94 & 21.94 & 21.94 & 21.09 & 21.09 & 21.09 & 21.09 \\
\hline Calcium (\%) & 0.971 & 0.971 & 0.971 & 0.971 & 0.878 & 0.878 & 0.878 & 0.878 \\
\hline Avaiable phosphorus (\%) & 0.463 & 0.463 & 0.463 & 0.463 & 0.419 & 0.419 & 0.419 & 0.419 \\
\hline Sodium $(\%)$ & 0.225 & 0.225 & 0.225 & 0.225 & 0.218 & 0.218 & 0.218 & 0.218 \\
\hline Digestible Lys (\%) & 1.307 & 1.307 & 1.307 & 1.307 & 1.256 & 1.256 & 1.256 & 1.256 \\
\hline Digestible Met+cys (\%) & 0.967 & 0.967 & 0.967 & 0.967 & 0.929 & 0.929 & 0.929 & 0.929 \\
\hline Digestible Thr (\%) & 0.863 & 0.863 & 0.863 & 0.863 & 0.829 & 0.829 & 0.829 & 0.829 \\
\hline
\end{tabular}

ASO, acid soybean oil; DSO, degummed soybean oil; ME, metabolizable energy.

1) Mineral supplement, per kg of diet: $50 \mathrm{mg}$ iron; $10 \mathrm{mg}$ copper; $65 \mathrm{mg}$ manganese; $65 \mathrm{mg}$ zinc; $1 \mathrm{mg}$ iodine.

2) Vitamin supplement, per $\mathrm{kg}$ of diet: $14,300 \mathrm{IU}$ vitamin $\mathrm{A} ; 5,200 \mathrm{IU}$ vitamin $\mathrm{D}_{3} ; 71.5 \mathrm{IU}$ vitamin $\mathrm{E}_{3} 3.9 \mathrm{mg}$ vitamin $\mathrm{K}_{3} ; 2.99 \mathrm{mg}$ vitamin $\mathrm{B}_{1} ; 9.10 \mathrm{mg}$ vitamin $\mathrm{B}_{2}$; $15.6 \mathrm{mg}$ pantothenic acid; $5.2 \mathrm{mg}$ vitamin $\mathrm{B}_{6} ; 3.25 \mathrm{mcg}$ vitamin $\mathrm{B}_{12} ; 78 \mathrm{mg}$ nicotinic acid; $2.6 \mathrm{mg}$ folic acid; 325 mcg biotin; 390 mcg selenium.

3) The inclusion of the emulsifier was performed in substitution to the inert Kaolin = mineral kaolinite (São Carlos, SP, Brazil).

(pH 8) containing $50 \mathrm{mM} \mathrm{CaCl}_{2}$ [10]. Lipase activity was obtained using 2,3-dimercaptopropanol tributyrate (BALB) as substrate and dithiobis-2-nitrobenzoic acid (DTNB) as chromophore (BALB-DNTP method, Gold Analisa, Belo Horizonte, MG, Brazil). Enzyme activity was expressed as international units (IU) per milligram of protein, according to Bradford's method [11].

\section{Intestinal morphology}

For morphological analyses, fragments of approximately $5 \mathrm{~cm}$ in length of the duodenum and jejunum of birds slaughtered at 14 and 21 days were taken to evaluate villus height, crypt depth, villus height to crypt depth ratio, and absorptive area. For sampling, the small intestine segments were divided into duodenum (from pylorus to distal duodenal loop) and jejunum (from distal duodenal loop to Meckel's diverticulum). The fragments were fixed in buffered formalin solution (10\%), dehydrated with a graded alcohol series, and embedded in paraffin. The $5-\mu \mathrm{m}$ thick sections of each segment were mounted on glass slides and stained with hematoxylin and eosin, according to Luna [12]. Measurements were performed using the PROPLUS image system 4.1. Thirty villi and crypts were measured in each sample to evaluate villus height, villus width, crypt width, and crypt depth. The morphometric measurements were used to calculate the absorptive surface area of the intestinal mucosa according to the formula proposed by Kisielinski et al [13]: Absorption area $=\left([\mathrm{WV} \times \mathrm{HV}]+[\mathrm{WV} / 2+\mathrm{WC} / 2]^{2}\right.$ $\left.-[\mathrm{WV} / 2]^{2}\right) /\left([\mathrm{WV} / 2+\mathrm{WC} / 2]^{2}\right)$, where $\mathrm{WV}$ is the width of the villus, $\mathrm{HV}$ is the height of the villus, and $\mathrm{WC}$ is the width of the crypt. The villus height to crypt depth ratio was also calculated.

\section{Ileal digestibility}

Nutrient digestibility and digestible energy (DE) content were determined using the ileal digestibility method in broilers at 49 days of age. A source of silica, Celite (Lompoc, CA, USA), was added to all experimental diets as an indigestible marker 
Table 2. Ingredients and chemical composition of experimental diets containing different lipid sources, with or without inclusion of emulsifier, for the grower I (22 to 33 days) and grower II (34 to 42 days) phases of broilers

\begin{tabular}{|c|c|c|c|c|c|c|c|c|}
\hline \multirow{3}{*}{ Items } & \multicolumn{4}{|c|}{22 to 33 days } & \multicolumn{4}{|c|}{34 to 42 days } \\
\hline & \multicolumn{2}{|c|}{ ASO } & \multicolumn{2}{|c|}{ DSO } & \multicolumn{2}{|c|}{ ASO } & \multicolumn{2}{|c|}{ DSO } \\
\hline & With & Without & With & Without & With & Without & With & Without \\
\hline Corn & 63.80 & 65.25 & 64.91 & 66.04 & 69.67 & 71.13 & 70.56 & 71.70 \\
\hline Soybean meal, $46 \%$ & 25.90 & 25.70 & 25.70 & 25.50 & 21.00 & 20.80 & 20.90 & 20.70 \\
\hline Meat and bone meal, 45\% & 3.00 & 3.00 & 3.00 & 3.00 & 3.00 & 3.00 & 3.00 & 3.00 \\
\hline DSO & - & - & 2.66 & 1.72 & - & - & 2.30 & 1.36 \\
\hline Poultry fat & 1.00 & 1.00 & 1.00 & 1.00 & 1.00 & 1.00 & 1.00 & 1.00 \\
\hline Dicalcium phosphate & 0.687 & 0.685 & 0.686 & 0.684 & 0.302 & 0.300 & 0.301 & 0.299 \\
\hline Limestone & 0.374 & 0.377 & 0.376 & 0.378 & 0.337 & 0.340 & 0.339 & 0.341 \\
\hline $\mathrm{NaCl}$ & 0.439 & 0.438 & 0.438 & 0.438 & 0.412 & 0.412 & 0.412 & 0.412 \\
\hline Mineral supplement ${ }^{1)}$ & 0.050 & 0.050 & 0.050 & 0.050 & 0.050 & 0.050 & 0.050 & 0.050 \\
\hline Choline chloride, $60 \%$ & 0.060 & 0.060 & 0.060 & 0.060 & 0.060 & 0.060 & 0.060 & 0.060 \\
\hline Inert $^{3)}$ & 0.035 & 0.035 & 0.035 & 0.035 & 0.035 & 0.035 & 0.035 & 0.035 \\
\hline ME (kcal/kg) & 3,150 & 3,100 & 3,150 & 3,100 & 3,200 & 3,150 & 3,200 & 3,150 \\
\hline Crude protein (\%) & 18.61 & 18.61 & 18.61 & 18.61 & 16.79 & 16.79 & 16.79 & 16.79 \\
\hline Calcium (\%) & 0.758 & 0.758 & 0.758 & 0.758 & 0.634 & 0.634 & 0.634 & 0.634 \\
\hline Avaiable phosphorus (\%) & 0.374 & 0.374 & 0.374 & 0.374 & 0.296 & 0.296 & 0.296 & 0.296 \\
\hline Sodium (\%) & 0.208 & 0.208 & 0.208 & 0.208 & 0.197 & 0.197 & 0.197 & 0.197 \\
\hline Digestible Lys (\%) & 1.124 & 1.124 & 1.124 & 1.124 & 1.014 & 1.014 & 1.014 & 1.014 \\
\hline Digestible Met+cys (\%) & 0.832 & 0.832 & 0.832 & 0.832 & 0.750 & 0.750 & 0.750 & 0.750 \\
\hline Digestible Thr (\%) & 0.742 & 0.742 & 0.742 & 0.742 & 0.669 & 0.669 & 0.669 & 0.669 \\
\hline
\end{tabular}

ASO, acid soybean oil; DSO, degummed soybean oil; ME, metabolizable energy.

1) Mineral supplement, per kg of diet: 50 mg iron; 10 mg copper; 65 mg manganese; 65 mg zinc; 1 mg iodine.

2) Vitamin supplement, per $\mathrm{kg}$ of diet: $11,000 \mathrm{IU}$ vitamin $\mathrm{A} ; 4,000 \mathrm{IU}$ vitamin $\mathrm{D}_{3} ; 55 \mathrm{IU}$ vitamin $\mathrm{E}_{3} ; 3 \mathrm{mg}$ vitamin $\mathrm{K}_{3} ; 2.3 \mathrm{mg}$ vitamin $\mathrm{B}_{1} ; 7 \mathrm{mg}$ vitamin $\mathrm{B}_{2} ; 12 \mathrm{mg}$ pantothenic acid; $4 \mathrm{mg}$ vitamin $\mathrm{B}_{6} ; 2.5 \mathrm{mcg}$ vitamin $\mathrm{B}_{12} ; 60 \mathrm{mg}$ nicotinic acid; $2 \mathrm{mg}$ folic acid; $250 \mathrm{mcg}$ biotin; $300 \mathrm{mcg}$ selenium.

3) The inclusion of the emulsifier was performed in substitution to the inert Kaolin = mineral kaolinite (São Carlos, SP, Brazil).

at $1 \%$ for 7 days. After adaptation to the diets, two representative birds per EU (mean weight $\pm 5 \%$ ) were individually weighed and slaughtered by cervical dislocation. Ileal digesta from the Meckel's diverticulum to approximately $4 \mathrm{~cm}$ proximal to the ileocecal junction were collected. Samples of ileal digesta were homogenized and immediately oven-dried at $55^{\circ} \mathrm{C}$ for 72 hours. After drying, ileal digesta samples and experimental diets were ground and sent to the laboratory for analysis of $\mathrm{DM}$, ash, crude protein (CP), gross energy (GE), and acid-insoluble ash (AIA). The DM, ash, and CP analyzed by the Kjeldahl method, were determined according to the AOAC [14]. The samples were pelleted and combusted in a bomb calorimeter for determination of GE. The AIA was determined according to the method of Van Keulen and Young [15]. Then, the digestibility coefficients (DC) of DM, ash, and $\mathrm{CP}$, as well as the $\mathrm{DE}$ values were calculated [9].

\section{Statistical analysis}

Data normality was evaluated using the Shapiro Wilk test.
The data were submitted to analysis of variance using the SAS Software (SAS Inst. Inc., Cary, NC, USA). When significant, the factors were compared using the F-test at a significance level of $5 \%$.

\section{RESULTS}

There was a significant interaction between lipid sources and dietary inclusion of emulsifier on WG $(\mathrm{p}=0.018)$ and FCR ( $p=0.046)$ of broilers from 1 to 35 days of age. The unfolding of interaction showed that broilers fed diets containing ASO without emulsifier had higher WG than DSOfed animals (2,520 g vs 2,412 g). Moreover, broilers fed ASObased diets with the inclusion of emulsifier had worse FCR than birds receiving diets with DSO plus emulsifier (1.491 vs 1.473 ) and than those receiving the same lipid source but without the emulsifying agent (1.491 vs 1.450$)$. The analysis of isolated factors showed that the FCR of birds fed diets with emulsifier worsened regardless of lipid source from 1 
Table 3. Ingredients and chemical composition of experimental diets containing different lipid sources with or without inclusion of emulsifier for the finisher (42 to 49 days) phase of broilers

\begin{tabular}{|c|c|c|c|c|}
\hline \multirow{2}{*}{ Items } & \multicolumn{2}{|c|}{ ASO } & \multicolumn{2}{|c|}{ DSO } \\
\hline & With & Without & With & Without \\
\hline \multicolumn{5}{|l|}{ Ingredients (\%) } \\
\hline Corn & 69.68 & 71.22 & 71.09 & 72.12 \\
\hline Soybean meal, 46\% & 18.90 & 18.60 & 18.60 & 18.50 \\
\hline Meat and bone meal, 45\% & 3.00 & 3.00 & 3.00 & 3.00 \\
\hline ASO & 4.39 & 3.14 & - & - \\
\hline DSO & - & - & 3.27 & 2.34 \\
\hline Poultry fat & 1.00 & 1.00 & 1.00 & 1.00 \\
\hline Dicalcium phosphate & 0.191 & 0.189 & 0.189 & 0.188 \\
\hline Limestone & 0.289 & 0.292 & 0.291 & 0.293 \\
\hline $\mathrm{NaCl}$ & 0.400 & 0.400 & 0.400 & 0.400 \\
\hline Mineral supplement ${ }^{1)}$ & 0.050 & 0.050 & 0.050 & 0.050 \\
\hline Vitamin supplement ${ }^{2)}$ & 0.100 & 0.100 & 0.100 & 0.100 \\
\hline DL-methionine, 99\% & 0.270 & 0.269 & 0.269 & 0.268 \\
\hline L-threonine, 98\% & 0.099 & 0.099 & 0.099 & 0.099 \\
\hline L-lysine HCL, 51\% & 0.537 & 0.544 & 0.543 & 0.549 \\
\hline Choline chloride, $60 \%$ & 0.060 & 0.060 & 0.060 & 0.060 \\
\hline Inert ${ }^{3)}$ & 0.035 & 0.035 & 0.035 & 0.035 \\
\hline Celite & 1.000 & 1.000 & 1.000 & 1.000 \\
\hline ME (kcal/kg) & 3,250 & 3,200 & 3,250 & 3,200 \\
\hline Crude protein (\%) & 15.79 & 15.79 & 15.79 & 15.79 \\
\hline Calcium (\%) & 0.581 & 0.581 & 0.581 & 0.581 \\
\hline Avaiable phosphorus (\%) & 0.271 & 0.271 & 0.271 & 0.271 \\
\hline Sodium (\%) & 0.192 & 0.192 & 0.192 & 0.192 \\
\hline Digestible Lys (\%) & 0.954 & 0.954 & 0.954 & 0.954 \\
\hline Digestible Met+cys (\%) & 0.706 & 0.706 & 0.706 & 0.706 \\
\hline Digestible Thr (\%) & 0.630 & 0.630 & 0.630 & 0.630 \\
\hline
\end{tabular}

ASO, acid soybean oil; DSO, degummed soybean oil; ME, metabolizable energy.

${ }^{1)}$ Mineral supplement, per $\mathrm{kg}$ of diet: $50 \mathrm{mg}$ iron; $10 \mathrm{mg}$ copper; $65 \mathrm{mg}$ manganese; $65 \mathrm{mg}$ zinc; $1 \mathrm{mg}$ iodine.

2) Vitamin supplement, per $\mathrm{kg}$ of diet: 11,000 IU vitamin A; 4,000 IU vitamin $\mathrm{D}_{3} ; 55 \mathrm{IU}$ vitamin $\mathrm{E} ; 3 \mathrm{mg}$ vitamin $\mathrm{K}_{3} ; 2.3 \mathrm{mg}$ vitamin $\mathrm{B}_{1} ; 7 \mathrm{mg}$ vitamin $\mathrm{B}_{2} ; 12 \mathrm{mg}$ pantothenic acid; $4 \mathrm{mg}$ vitamin $\mathrm{B}_{6} ; 2.5$ mcg vitamin $\mathrm{B}_{12} ; 60 \mathrm{mg}$ nicotinic acid; $2 \mathrm{mg}$ folic acid; $250 \mathrm{mcg}$ biotin; $300 \mathrm{mcg}$ selenium.

3) The inclusion of the emulsifier was performed in substitution to the inert Caulim Kaolin = mineral kaolinite (São Carlos, SP, Brazil).

to 21 days $(\mathrm{p}=0.006)$ and from 1 to 49 days $(\mathrm{p}=0.0002)$ (Table 4).

No interaction ( $p>0.05)$ was observed between the studied factors on liver and pancreas relative weights at 14 and 21 days of age. However, birds fed diets containing ASO had higher $(\mathrm{p}=0.026)$ relative pancreas weight at 14 days of age than DSO-fed animals, regardless of dietary inclusion of emulsifier $(0.45 \%$ vs $0.41 \%$, Table 5$)$. There was no interaction ( $p>0.05$ ) between lipid source and emulsifier inclusion on lipase activity at 14 and 21 days of age. Despite the influence of lipid source on the relative pancreas weight at 14 days of age, no significant effect of isolated factors ( $p>0.05$ ) was observed for lipase activity (Table 6).

Morphometric parameters (villus height, crypt depth, villus height to crypt depth ratio, and absorptive area) of the duodenum and jejunum segments at 14 and 21 days were not influenced $(\mathrm{p}>0.05)$ by lipid sources and emulsifier inclusion (Tables 7,8 ).

There was an interaction $(\mathrm{p}=0.053)$ between lipid source and emulsifier inclusion on DE content. The analysis within each lipid source showed that the emulsifier led to better use of the ASO, resulting in higher DE $(3,084 \mathrm{kcal} / \mathrm{kg}$ vs 2,904 $\mathrm{kcal} / \mathrm{kg}$ ). The dietary inclusion of emulsifier led to higher DE for ASO than DSO $(3,084 \mathrm{kcal} / \mathrm{kg}$ vs $2,847 \mathrm{kcal} / \mathrm{kg})$. No effect of treatments ( $p>0.05)$ was observed for nutrient DCs (Table 9).

\section{DISCUSSION}

Although ASO is considered a source with reduced use by broilers due to its high content of free fatty acids, the dietary inclusion of this alternative lipid source improved the WG of broilers from 1 to 35 days of age and did not impair their morphophysiological characteristics. Rodriguez-Sanchez et al [4] reported higher WG at 21 days in broilers fed diets with $15 \%$ of free fatty acids. In this study, the DE values of ASO and DSO in diets without the emulsifying agent were similar, as also observed by Rodrigues-Sanchez et al [4]. These authors suggest that this result may be related to the presence of free fatty acids in the diet, which are the final products of lipid digestion and do not influence the activity of pancreatic lipase. Moreover, free fatty acids participate in triglyceride emulsification [16] and induce the formation of a high-affinity complex between lipase and colipase [17], which increases the hydrolytic activity of lipase. In addition, the difference in the chemical structure of fatty acids of the lipid sources used in this trial was lower than expected considering the data reported in the literature [2], which may have favored the use by the birds. The ASO presented $47.5 \%$ of linoleic acid, $4.6 \%$ of linolenic acid, and $28.5 \%$ of oleic acid compared to $53.1 \%$, $7 \%$, and $24.7 \%$ of DSO, respectively. Borsatti et al [3] stated that ASO, besides being an adequate energy source for broilers, reduces production costs and can be used as an alternative to DSO in the poultry industry.

Given that the morphophysiological changes in broilers are most pronounced during the starter phase (1 to 21 days), especially in relation to lipase activity and secretion of bile salts $[5,18]$, we decided to evaluate the effects of lipid sources and emulsifier on organ weight, lipase activity in the pancreas, and intestinal morphometry at 14 and 21 days of age. Despite evidence that the studied factors may interfere with the above-mentioned parameters $[19,20]$, no changes were observed in our study, except for the influence of lipid source on relative pancreas weight at 14 days of age.

Feeding lipid sources may change pancreatic lipase activity [21], and pancreas weight is an indirect measure of pancreatic 
Table 4. Growth performance of broilers fed diets containing different lipid sources, with or without emulsifier

\begin{tabular}{|c|c|c|c|c|c|c|c|c|c|c|c|c|c|}
\hline \multirow{2}{*}{ Items } & \multirow{2}{*}{$\begin{array}{l}\text { Lipid } \\
\text { source }\end{array}$} & \multicolumn{3}{|c|}{ 1-7 days } & \multicolumn{3}{|c|}{ 1-21 days } & \multicolumn{3}{|c|}{$1-35$ days } & \multicolumn{3}{|c|}{ 1-49 days } \\
\hline & & WG & AFI & FCR & WG & AFI & FCR & WG & AFI & FCR & WG & AFI & FCR \\
\hline \multicolumn{14}{|l|}{ Emulsifier } \\
\hline+ & ASO & 150.69 & 170.34 & 1.131 & $1,003.03$ & $1,292.97$ & 1.289 & $2,450.58$ & $3,653.77$ & $1.491^{\mathrm{Aa}}$ & $3,876.50$ & $6,658.10$ & 1.718 \\
\hline+ & DSO & 152.10 & 171.17 & 1.127 & 994.99 & $1,285.78$ & 1.292 & $2,466.51$ & $3,632.96$ & $1.473^{b}$ & $3,837.95$ & $6,585.79$ & 1.717 \\
\hline- & ASO & 149.44 & 166.34 & 1.114 & $1,020.09$ & $1,291.63$ & 1.266 & $2,520.49^{a}$ & $3,653.16$ & $1.450^{\mathrm{B}}$ & $3,994.59$ & $6,692.70$ & 1.676 \\
\hline- & DSO & 150.34 & 171.76 & 1.144 & $1,002.54$ & $1,277.44$ & 1.274 & $2,412.24^{b}$ & $3,550.14$ & 1.471 & $3,874.32$ & $6,464.38$ & 1.669 \\
\hline SEM & & 7.53 & 6.61 & 0.03 & 0.25 & 35.1 & 0.02 & 69.64 & 118.24 & 0.03 & 198.7 & 313.93 & 0.03 \\
\hline \multicolumn{14}{|l|}{ Emulsifier } \\
\hline+ & & 151.40 & 170.76 & 1.129 & 998.74 & $1,289.13$ & 1.291 & $2,458.55$ & $3,643.37$ & 1.482 & $3,857.22$ & $6,621.95$ & 1.717 \\
\hline- & & 149.89 & 169.05 & 1.129 & $1,011.32$ & $1,284.53$ & 1.270 & $2,466.37$ & $3,601.65$ & 1.460 & $3,934.46$ & $6,578.54$ & 1.672 \\
\hline \multicolumn{14}{|l|}{ Lipid source } \\
\hline ASO & & 150.07 & 168.34 & 1.122 & $1,011.56$ & $1,292.30$ & 1.278 & $2,485.54$ & $3,653.47$ & 1.470 & $3,935.54$ & $6,675.40$ & 1.697 \\
\hline DSO & & 151.22 & 171.47 & 1.135 & 998.51 & $1,281.89$ & 1.284 & $2,439.38$ & $3,591.55$ & 1.472 & $3,856.14$ & $6,525.09$ & 1.693 \\
\hline CV (\%) & & 5.00 & 3.89 & 3.06 & 2.47 & 2.73 & 1.43 & 2.83 & 3.20 & 1.84 & 5.10 & 4.76 & 4.78 \\
\hline $\mathrm{p}$-value $\mathrm{O} \times \mathrm{E}$ & & 0.924 & 0.335 & 0.176 & 0.611 & 0.791 & 0.715 & 0.018 & 0.334 & 0.046 & 0.565 & 0.488 & 0.774 \\
\hline p-value oil (0) & & 0.668 & 0.192 & 0.305 & 0.177 & 0.421 & 0.400 & 0.071 & 0.150 & 0.856 & 0.268 & 0.187 & 0.715 \\
\hline $\mathrm{p}$-value emulsifier (E) & & 0.577 & 0.472 & 0.997 & 0.194 & 0.714 & 0.006 & 0.753 & 0.327 & 0.032 & 0.281 & 0.699 & 0.0002 \\
\hline
\end{tabular}

WG, weight gain (g); AFI, average feed intake (g); FCR, feed conversion rate $(\mathrm{g} / \mathrm{g}) ;+$, with emulsifier; -, without emulsifier; SEM, standard error of the mean; ASO, acid soybean oil; DSO, degummed soybean oil; CV, coefficient of variation.

$A-B / a-b$ In the same column, means followed by uppercase letters or lowercase letters differed $(p<0.05)$ regarding the type of lipid source or the inclusion or not of the emulsifier, respectively.

activity as it is directly associated with endogenous enzyme production. Sakomura et al [21] report that the growth of the pancreas coincided with an increase in the production of digestive enzymes. The ASO has a lower digestibility than DSO $[1,4]$ due to its fatty acid profile. Therefore, the higher relative pancreas weight could be related to the higher demand for lipase. However, this relationship was not observed in this study as the different lipid sources did not affect lipase activity in the pancreas.

The emulsifier used in this study (glyceryl polyethyleneg- lycol ricinoleate) is extracted from an oil source and acts as a feed additive, i.e., it helps increase energy supply to poultry $[7,22]$. During the first week of the experiment, inclusion of the emulsifier compensated for the $40 \mathrm{kcal} / \mathrm{kg}$ decrease in apparent metabolizable energy requirement of birds, regardless of the lipid source used, since performance was similar between groups fed diets with and without the emulsifier. After this period, the influence of the emulsifier on the processes of lipid digestion and absorption was not able to compensate for the decrease in dietary energy, which resulted in a worse

Table 5. Relative weight (\%) of liver and pancreas of broilers fed diets containing different lipid sources, with or without emulsifier

\begin{tabular}{|c|c|c|c|c|c|}
\hline \multirow{2}{*}{ Items } & \multirow{2}{*}{ Lipid source } & \multicolumn{2}{|c|}{14 days } & \multicolumn{2}{|c|}{21 days } \\
\hline & & Liver & Pancreas & Liver & Pancreas \\
\hline \multicolumn{6}{|l|}{ Emulsifier } \\
\hline+ & ASO & 3.60 & 0.46 & 3.22 & 0.35 \\
\hline+ & DSO & 3.61 & 0.42 & 3.33 & 0.34 \\
\hline- & ASO & 3.44 & 0.44 & 3.37 & 0.32 \\
\hline- & DSO & 3.41 & 0.40 & 3.06 & 0.33 \\
\hline SEM & & 0.50 & 0.04 & 0.31 & 0.03 \\
\hline \multicolumn{6}{|l|}{ Emulsifier } \\
\hline+ & & 3.60 & $0.44^{\mathrm{a}}$ & 3.28 & 0.34 \\
\hline- & & 3.42 & $0.42^{b}$ & 3.21 & 0.32 \\
\hline \multicolumn{6}{|l|}{ Lipid source } \\
\hline ASO & & 3.52 & 0.45 & 3.29 & 0.34 \\
\hline DSO & & 3.51 & 0.41 & 3.19 & 0.33 \\
\hline CV $(\%)$ & & 14.21 & 10.39 & 9.54 & 10.12 \\
\hline$p$-value $O \times E$ & & 0.908 & 0.931 & 0.068 & 0.368 \\
\hline p-value oil (0) & & 0.952 & 0.026 & 0.363 & 0.623 \\
\hline p-value emulsifier (E) & & 0.328 & 0.220 & 0.556 & 0.103 \\
\hline
\end{tabular}

+, with emulsifier; -, without emulsifier; ASO, acid soybean oil; DSO, degummed soybean oil; SEM, standard error of the mean; CV, coefficient of variation.

$a, b$ In the same column, means followed by lowercase letters differed $(p<0.05)$ regarding the type of lipid source. 
Table 6. Lipase activity (UI/mg of protein) in pancreas of broilers fed diets containing different lipid sources, with or without emulsifier

\begin{tabular}{lccc}
\hline Items & Lipid source & $\mathbf{1 4}$ days & 21 days \\
\hline Emulsifier & & & \\
+ & ASO & 7.22 & 24.13 \\
+ & DSO & 5.40 & 21.17 \\
- & ASO & 6.02 & 21.18 \\
- & DSO & 5.76 & 18.03 \\
SEM & & 2.66 & 10.64 \\
Emulsifier & & & \\
+ & & 5.78 & 22.65 \\
- & & 5.37 & 19.61 \\
Lipid source & & & \\
$\quad$ ASO & & 6.11 & 22.66 \\
$\quad$ DSO & & 5.04 & 19.60 \\
CV (\%) & & 47.72 & 50.35 \\
p-value OxE & & 0.765 & 0.981 \\
p-value oil (O) & & 0.270 & 0.423 \\
p-value emulsifier (E) & & 0.625 & 0.425 \\
\hline
\end{tabular}

+, with emulsifier; -, without emulsifier; ASO, acid soybean oil; DSO, degummed soybean oil; SEM, standard error of the mean; CV, coefficient of variation.

FCR.

Exogenous emulsifiers, as well as bile salts, form a bridge between water- and fat-soluble materials and increase the active surface of fats [23]. As a result, emulsifying agents enhance the action of lipase, which helps to hydrolyze triglyceride molecules into fatty acids and monoglycerides [24] and favors the formation of micelles consisting of lipolysis products. Thus, the additive may have been effective in influencing the processes of lipid digestion and absorption during the first week of life because starter chicks have a physiological limitation regarding the production of bile salts and endogenous lipase [5]. The fact that the emulsifying agent did not affect lipase activity in the pancreas can lead to the hypothesis that this additive influences the processes of lipid digestion and absorption, such as facilitating micelle formation, indirectly enhancing the activity of lipase in the gastrointestinal tract. The energy values of DSO for broilers increased up to 21 days of age, as reported by Bertechini et al [25], which indicates the development of the digestive system up to 21 days and improvement in lipid use. Khonyoung et al [26] reported that feeding lysolecithin as an emulsifier improved broiler performance up to 21 days of age, which demonstrates that the addition of an emulsifier to broiler diets would improve the use of dietary lipids up to 21 days of age.

Given the results on performance and digestibility, it is essential to highlight that the difference in the chemical structure of the fatty acids present in the lipid sources did not interfere with lipid use by the birds, despite the influence of the emulsifier on the DE content. The inclusion of the emulsifier in diets with ASO increased the DE content by $6.2 \%$. The ASO is a residue obtained from the neutralization of soybean oil for human consumption. It corresponds to approximately $6 \%$ of the raw material and is composed of a mixture of free fatty acids, mono-, and diglycerides [27]. The high concentration of free fatty acids is correlated with reduced digestibility due to an inefficient emulsification process, which negatively interferes with micelle formation and, consequently, lipid absorption [3,27]. The dietary in-

Table 7. Villus height, crypt depth, villus:crypt ratio, and area of absorption of duodenum of broilers fed diets containing different lipid sources, with or without emulsifier

\begin{tabular}{|c|c|c|c|c|c|c|c|c|c|}
\hline \multirow{2}{*}{ Items } & \multirow{2}{*}{ Lipid source } & \multicolumn{4}{|c|}{14 days } & \multicolumn{4}{|c|}{21 days } \\
\hline & & VH & CD & $\mathrm{V}: \mathrm{C}$ & AA & VH & CD & $\mathrm{V}: \mathrm{C}$ & AA \\
\hline \multicolumn{10}{|l|}{ Emulsifier } \\
\hline+ & DSO & 823.05 & 48.63 & 17.96 & 20.75 & 848.64 & 61.09 & 14.02 & 19.13 \\
\hline- & ASO & 870.87 & 47.52 & 18.90 & 20.28 & 874.95 & 64.52 & 13.95 & 17.82 \\
\hline- & DSO & 768.30 & 46.89 & 16.80 & 20.17 & 871.60 & 71.19 & 12.57 & 18.87 \\
\hline+ & & 849.85 & 49.84 & 18.45 & 21.09 & 848.21 & 62.97 & 13.60 & 18.94 \\
\hline- & & 824.25 & 47.23 & 17.95 & 20.23 & 873.15 & 68.11 & 13.20 & 17.80 \\
\hline \multicolumn{10}{|l|}{ Lipid source } \\
\hline ASO & & 871.53 & 49.18 & 18.16 & 20.83 & 861.37 & 64.69 & 13.57 & 18.29 \\
\hline DSO & & 795.67 & 47.76 & 18.22 & 20.46 & 861.00 & 66.52 & 13.24 & 18.46 \\
\hline
\end{tabular}

$\mathrm{VH}$, villus height $(\mu \mathrm{m}) ; \mathrm{CD}$, crypt depth $(\mu \mathrm{m}) ; \mathrm{V}: \mathrm{C}$, villus:crypt ratio; $\mathrm{AA}$, area of absorption $\left(\mu \mathrm{m}^{2}\right)$; + , with emulsifier; - , without emulsifier; $\mathrm{ASO}$, acid soybean oil; DSO, degummed soybean oil; SEM, standard error of the mean; CV, coefficient of variation. 
Table 8. Villus height, crypt depth, villus:crypt ratio, and area of absorption of jejunum of broilers fed diets containing different lipid sources, with or without emulsifier

\begin{tabular}{|c|c|c|c|c|c|c|c|c|c|}
\hline \multirow{2}{*}{ Items } & \multirow{2}{*}{ Lipid source } & \multicolumn{4}{|c|}{14 days } & \multicolumn{4}{|c|}{21 days } \\
\hline & & VH & $C D$ & $\mathrm{~V}: \mathrm{C}$ & AA & VH & $C D$ & $\mathrm{~V}: \mathrm{C}$ & AA \\
\hline \multicolumn{10}{|l|}{ Emulsifier } \\
\hline+ & ASO & 332.29 & 38.17 & 8.72 & 8.66 & 410.87 & 47.20 & 8.70 & 9.81 \\
\hline+ & DSO & 383.45 & 45.04 & 8.73 & 9.05 & 379.26 & 46.84 & 8.12 & 8.34 \\
\hline- & ASO & 374.06 & 41.61 & 9.12 & 9.40 & 422.05 & 49.88 & 8.48 & 8.93 \\
\hline - & DSO & 347.58 & 39.92 & 8.88 & 8.82 & 455.01 & 55.61 & 8.34 & 9.73 \\
\hline SEM & & 62.68 & 8.46 & 1.43 & 1.19 & 83.75 & 9.03 & 0.82 & 1.56 \\
\hline \multicolumn{10}{|l|}{ Emulsifier } \\
\hline+ & & 344.18 & 41.60 & 8.72 & 8.85 & 395.07 & 47.02 & 8.41 & 9.08 \\
\hline- & & 361.70 & 40.82 & 9.01 & 9.13 & 422.87 & 49.65 & 8.41 & 9.36 \\
\hline \multicolumn{10}{|l|}{ Lipid source } \\
\hline ASO & & 354.57 & 40.00 & 8.93 & 9.06 & 416.03 & 48.43 & 8.60 & 9.41 \\
\hline DSO & & 352.41 & 42.48 & 8.81 & 8.93 & 399.77 & 48.04 & 8.23 & 9.04 \\
\hline CV (\%) & & 17.73 & 20.74 & 16.16 & 13.20 & 20.53 & 18.73 & 9.75 & 16.97 \\
\hline$p$-value $O \times E$ & & 0.284 & 0.191 & 0.818 & 0.282 & 0.619 & 0.989 & 0.500 & 0.072 \\
\hline p-value oil (0) & & 0.988 & 0.423 & 0.834 & 0.823 & 0.654 & 0.912 & 0.268 & 0.586 \\
\hline p-value emulsifier (E) & & 0.517 & 0.794 & 0.608 & 0.565 & 0.408 & 0.467 & 1.000 & 0.678 \\
\hline
\end{tabular}

$\mathrm{VH}$, villus height $(\mu \mathrm{m}) ; \mathrm{CD}$, crypt depth $(\mu \mathrm{m})$; V:C, villus:crypt ratio; $\mathrm{AA}$, area of absorption $\left(\mu \mathrm{m}^{2}\right)$; + , with emulsifier; -, without emulsifier; ASO, acid soybean oil; DSO, degummed soybean oil; SEM, standard error of the mean; CV, coefficient of variation.

clusion of emulsifiers is expected to increase the digestibility of lipid sources by promoting the incorporation of fatty acids into micelles, especially free fatty acids [28]. In this study,

Table 9. Average values of digestible energy $(\mathrm{kcal} / \mathrm{kg})$ and digestibility coefficients (\%) of dry matter, gross energy and crude protein determined in broilers at 49 days of age fed diets containing different lipid sources, with or without emulsifier

\begin{tabular}{lccccc}
\hline Items & $\begin{array}{c}\text { Lipid } \\
\text { source }\end{array}$ & DE & CDDM & CDGE & CDCP \\
\hline Emulsifier & & & & & \\
+ & ASO & $3,084^{\text {Aa }}$ & 67.85 & 71.18 & 66.26 \\
+ & DSO & $2,847^{\mathrm{b}}$ & 67.51 & 69.48 & 69.79 \\
- & ASO & $2,904^{\mathrm{B}}$ & 66.83 & 69.03 & 69.64 \\
- & DSO & 2,865 & 66.92 & 69.07 & 69.79 \\
SEM & & 78.34 & 1.78 & 1.90 & 2.40 \\
Emulsifier & & & & & \\
+ & & 2,965 & 67.67 & 70.33 & 68.03 \\
- & & 2,884 & 66.87 & 69.05 & 68.09 \\
Lipid source & & & & & \\
$\quad$ ASO & & 2,994 & 67.34 & 70.10 & 67.95 \\
$\quad$ DSO & & 2,856 & 67.21 & 69.27 & 68.17 \\
CV (\%) & & 3.00 & 2.93 & 3.02 & 6.38 \\
p-value OxE & & 0.053 & 0.834 & 0.426 & 0.153 \\
p-value oil (O) & & 0.008 & 0.896 & 0.446 & 0.922 \\
p-value emulsifier(E) & & 0.090 & 0.432 & 0.247 & 0.979 \\
\hline
\end{tabular}

$\mathrm{DE}$, digestible energy, dry matter basis; CDDM, coefficient of digestibility of dry matter; CDGE, coefficient of digestibility of gross energy; CDCP, coefficient of digestibility of crude protein; + , with emulsifier; -, without emulsifier; ASO, acid soybean oil; DSO, degummed soybean oil; SEM, standard error of the mean; $\mathrm{CV}$, coefficient of variation.

$A-B / a-b$ In the same column, means followed by uppercase letters or lowercase letters differed $(p<0.05)$ regarding the type of lipid source or the inclusion or not of the emulsifier, respectively. broilers fed diets containing ASO and the emulsifier had a higher DE than those fed DSO-based diets. However, the beneficial effect of the emulsifying agent could not counterbalance the feed conversion of broilers fed diets without nutrient reduction. This reduction may have been overestimated given the expected energy supply capacity of the additive. In a study evaluating the inclusion of an emulsifier similar to that used in our study in diets for broilers, Kulkarni et al [29] observed a positive effect of the emulsifying agent on feed conversion and metabolizable energy. However, the additive was top-dressed and was not considered in the nutritional matrix.

In conclusion, the addition of a glyceryl polyethyleneglycol ricinoleate-based emulsifier to diets with ASO and energy restriction maintained broiler performance in the first week of life, but worsened feed conversion in subsequent phases. ASO can be considered as an alternative lipid source to DSO and does not interfere with the morphophysiological characteristics and performance of broilers. The combination of ASO and emulsifier increased the DE content by $6.2 \%$.

\section{CONFLICT OF INTEREST}

We certify that there is no conflict of interest with any financial organization regarding the material discussed in the manuscript.

\section{FUNDING}

The authors received no financial support for this article. 


\section{ACKNOWLEDGMENTS}

This work was supported by the Coordenação de Aperfeiçoamento de Pessoal de Nível Superior (CAPES) (Brazil - Finance code 001) and Conselho Nacional de Desenvolvimento Científico e Tecnológico (CNPq) (Brazil).

\section{REFERENCES}

1. Rostagno HS, Albino LFT, Hannas MI, et al. Brazilian tables for poultry and swine: food composition and nutritional requirements. 4th ed. Viçosa, MG, Brazil: Universidade Federal de Viçosa; 2017.

2. Cortes-Cuevas A, Muñoz-Orozco JL, Gómez-Verduzco GG, Ávila-González E. Effect of two oil types and energy levels on broiler performance, carcass quality and skin pigmentation. Austral J Vet Sci 2018;50:89-94. https://doi.org/10. 4067/S0719-81322018000200089

3. Borsatti L, Vieira SL, Stefanello C, Kindlein L, OviedoRondón EO, Angel CR. Apparent metabolizable energy of by-products from the soybean oil industry for broilers: acidulated soapstock, glycerin, lecithin, and their mixture. Poult Sci 2018;97:124-30. https://doi.org/10.3382/ps/pex269

4. Rodriguez-Sanchez R, Tres A, Sala R, et al. Effects of dietary free fatty-acid content and saturation degree on lipid-class composition and fatty-acid digestibility along the gastrointestinal tract in broiler starter chickens. Poult Sci 2019;98: 4929-41. https://doi.org/10.3382/ps/pez253

5. Noy Y, Sklan D. Digestion and absorption in the young chick. Poult Sci 1995;74:366-73. https://doi.org/10.3382/ps.0740 366

6. Roy A, Haldar S, Mondal S, Ghosh TK. Effects of supplemental exogenous emulsifier on performance, nutrient metabolism, and serum lipid profile in broiler chickens. Vet Med Int 2010;2010: Article ID 262604. https://doi.org/10.4061/ 2010/262604

7. Kaczmarek SA, Bochenek M, Samuelsson AC, Rutkowski A. Effects of glyceryl polyethylene glycol ricinoleate on nutrient utilisation and performance of broiler chickens. Arch Anim Nutr 2015;69:285-96 https://doi.org/10.1080/1745039X.2015. 1061722

8. Udomprasert P, Rullwamsuk T. Effect of an exogenous emulsifier on growth performance in weanling pigs. Kasetysart J Nat Sci 2006;40:652-6.

9. Sakomura NK, Rostagno HS. Methods of research in non ruminant nutrition. 2th ed. Jaboticabal, SP, Brazil: Funep; 2016.

10. Pinheiro DF, Cruz VC, Sartori JR, Vicentini Paulino MLM. Effect of early feed restriction and enzyme supplementation on digestive enzyme activities in broilers. Poult Sci 2004;83: 1544-50. https://doi.org/10.1093/ps/83.9.1544

11. Bradford MM. A rapid and sensitive method for the quanti- tation of microgram quantities of protein utilizing the principle of protein-dye binding. Anal Biochem 1976;72:248-54. https:// doi.org/10.1016/0003-2697(76)90527-3

12.Luna GC. Manual of histologic staining methods of the armed forces. Institute of pathology. 3th ed. New York, USA: Mc GrawHill; 1968.

13. Kisielinski K, Willis S, Prescher A, Klosterhalfen B, Schumpelick V. A simple new method to calculate small intestine absorptive surface in the rat. Clin Exp Med 2002;2:131-5. https://doi. org/10.1007/s102380200018

14.AOAC. Official methods of analysis. 19th ed. Washington, DC, USA: AOAC Int.; 2012.

15. Van Keulen J, Young BA. Evaluation of acid insoluble ash as a natural marker in ruminant digestibility studies. J Anim Sci 1977;44:282-7. https://doi.org/10.2527/jas1977.442282x

16. Kindel T, Lee DM, Tso P. The mechanism of the formation and secretion of chylomicrons. Atheroscler Suppl 2010;11: 11-6. https://doi.org/10.1016/j.atherosclerosissup.2010.03.003

17.Larsson A, Erlanson-Albertsson C. Effect of phosphatidylcholine and free fatty acids on the activity of pancreatic lipasecolipase. Biochim Biophys Acta 1986;876:543-50. https:// doi.org/10.1016/0005-2760(86)90042-1

18. Krogdahl A, Sell JL. Influence of age on lipase, amylase, and protease activities in pancreatic tissue and intestinal contents of young turkeys. Poult Sci 1989;68:1561-8. https://doi.org/ 10.3382/ps.0681561

19. Guerreiro Neto AC, Pezzato AC, Sartori JR, et al. Emulsifier in broiler diets containing different fat sources. Braz J Poult Sci 2011;13;119-25. https://doi.org/10.1590/S1516-635X201 1000200006

20.Zavareie HN, Toghyani M. Effect of dietary phospholipids on performance, intestinal morphology and fat digestibility in broiler chicks. J Livest Sci 2018;9:107-15.

21. Sakomura NK, Del Bianchi M, Pizauro Jr JM, Café MB, Freitas ER. Effect of age on enzyme activity and nutrients digestibility for broilers fed soybean meal and full fat soybean. $\mathrm{R}$ Bras Zoot 2004;33:924-35. https://doi.org/10.1590/S151635982004000400013

22.Tan HS, Zulkifli I, Farjam AS, et al. Effect of exogenous emulsifier on growth performance, fat digestibility, apparent metabolisable energy in broiler chickens. J Biochem Microbiol Biotechnol 2016;4:7-10.

23.Al-Marzooqi W, Leeson S. Evaluation of dietary supplements of lipase, detergent, and crude porcine pancreas on fat utilization by young broiler chicks. Poult Sci 1999;78:15616. https://doi.org/10.1093/ps/78.11.1561

24. Ravindran V, Tancharoenrat P, Zaefarian F, Ravindran G. Fats in poultry nutrition: Digestive physiology and factors influencing their utilisation. Anim Feed Sci Technol 2016; 213:1-21. https://doi.org/10.1016/J.ANIFEEDSCI.2016.01. 012

25. Bertechini AG, Kato RK, Freitas LFV-B, Castro RTC, Mazzuco 
H. Metabolizable energy values of soybean meals and soybean oil for broilers at different ages. Acta Sci Anim Sci 2019;41: e44540. https://doi.org/10.4025/actascianimsci.v41i1.44540

26. Khonyoung D, Yamauchi K, Suzuki K. Influence of dietary fat sources and lysolecithin on growth performance, visceral organ size, and histological intestinal alteration in broiler chickens. Livest Sci 2015;176:111-20. https://doi.org/10.1016/ j.livsci.2015.03.011

27. Vieira SL, Ribeiro AML, Kessler AM, Fernandes LM, Ebert AR, Eichner G. Energy utilization of broiler feeds formulated with acidulated soybean soapstock. Braz J Poult Sci 2002;33: 127-39. https://doi.org/10.1590/S1516-635X2002000200005 28. Vieira SL, Kindlein L, Stefanello C, Simoes CT, Santiago GO, Machado LP. Energy utilization from various fat sources by broiler chickens at different ages. Int J Poult Sci 2015;14: 257-61. https://doi.org/10.3923/ijps.2015.257.261

29. Kulkarni RC, Dingore AD, Durge SM, Dinani OP, Amrutkar SA. Supplementation of different emulsifiers on performance of broilers. J Entomol Zool Stud 2019;7:25-9. 